\title{
Enrichment of Apatite-Bearing Iron Ore by Magnetic Separation and Flotation
}

\author{
M. Birinci (D) \\ İnonu University, Mining Engineering Department, 44280, Battalgazi, Malatya, Turkey. (e-mail: mustafa.birinci@inonu.edu.tr).
}

ARTICLE INFO

Received: Jan.,06.2021

Revised: Feb.,1.2021

Accepted: Feb.,19.2021

Keywords:

Magnetite

Apatite

Magnetic separation

Flotation

SEM-EDS

Corresponding author: $M$. Birinci

ISSN: 2536-5010 | e-ISSN: 2536-5134

DOI: https://doi.org/10.36222/ejt.866718

\section{ABSTRACT}

In this study, enrichment possibility of apatite-bearing iron ore sample was investigated to obtain iron and phosphate concentrate, separately. It was determined that the raw ore contains $35.75 \% \mathrm{Fe}$ and $5.36 \mathrm{P}_{2} \mathrm{O}_{5}$. Magnetite in the ore can be enriched with low-intensity magnetic separator, and apatite can be enriched from the non-magnetic product by flotation. For this purpose, the raw ore was ground below $106 \mathrm{~m}$ size and then subjected to magnetic separation (with two cleaner and one scavenger), and following flotation (with three cleaner and one scavenger).

According to the experimental result, a magnetic concentrate containing $63.55 \% \mathrm{Fe}$ and $1.65 \% \mathrm{P}_{2} \mathrm{O}_{5}$, and phosphate concentrate containing $25.33 \% \mathrm{P}_{2} \mathrm{O}_{5}$ and $6.45 \% \mathrm{Fe}$ were obtained. The results show that there are still difficulties to obtain plausible iron and phosphate concentrates in terms of phosphorus and iron impurities for iron and phosphate concentrate, respectively. It is concluded that it is hard to separate the iron and phosphorus phases from each other, possibly due to complex mineralogical composition and poor mineral liberation of the ore.

\section{INTRODUCTION}

With the developing industry and technology in the world, the demand for iron and steel is increasing continuously. Reserves of high-grade iron ore, that can be used directly in the iron and steel industry, are limited and are getting depleted very fast. In addition, it has become essential to prepare the iron concentrate to meet the specification of the steel industry. Physical methods such as gravity concentration, magnetic separation and flotation are standard practices to separate the gangue minerals from iron ores. However, the ores having ferromagnetic nature are suitable for being processed using magnetic separation methods [1]. For example, magnetite $\left(\mathrm{Fe}_{3} \mathrm{O}_{4}\right)$ is the most ferromagnetic of all the naturally occurring minerals on earth, and therefore low-intensity magnetic separators are widely used to upgrade magnetite ores.

Phosphorus is an important impurity and almost all of the phosphorus in iron ore transferred directly into cast iron during metallurgical processes. It is well known that steel containing high phosphorus is brittle, and therefore dephosphorization of iron ore is an important research topic. The only option to control phosphorus in the metal is limiting the amount of phosphorus in the ore. It is generally recommended that the phosphorus content of iron ore should be less than $0.1 \%$, though phosphorus limits vary according to steel-producing countries. Removal of phosphorus from certain iron ores has proven difficult, especially when phosphorus phases are associated with the iron phases in a very complicated manner. However, phosphorus can be removed from iron ore by physical processes (magnetic separation, flotation and selective agglomeration), chemical (leaching), thermal and bioleaching processes, as reported in the literature [2-5].

On the other hand, phosphorus is the common element in the earth's crust and is found in all living organisms. It is known that there are more than 200 phosphate minerals in the earth's crust, and structurally all have a $\left(\mathrm{PO}_{4}\right)$ tetrahedral unit. Approximately $95 \%$ of the world phosphate rock production is consumed in fertilizer manufacturing. The primary phosphate mineral is apatite $\left(\mathrm{Ca}_{5}\left(\mathrm{PO}_{4}\right)_{3}\left(\mathrm{~F}, \mathrm{Cl}, \mathrm{OH}, \mathrm{CO}_{3}\right)\right)$, and found in phosphate rock as: (a) fluorapatite $\left(\mathrm{Ca}_{5}\left(\mathrm{PO}_{4}\right)_{3} \mathrm{~F}\right)$, found mainly in igneous and metamorphic deposits, (b) chlorapatite $\left(\mathrm{Ca}_{5}\left(\mathrm{PO}_{4}\right)_{3} \mathrm{Cl}\right)$, found in igneous and metamorphic deposits, $(\mathrm{c})$ hydroxylapatite $\left(\mathrm{Ca}_{5}\left(\mathrm{PO}_{4}\right)_{3}(\mathrm{OH})\right)$, found in igneous and metamorphic deposits and, (d) carbonate-hydroxyl-apatite $\left(\mathrm{Ca}_{5}\left(\mathrm{PO}_{4}, \mathrm{CO}_{3}\right)_{3}(\mathrm{OH})\right)$, found mainly on islands as part of bird and bat excrements (e.g. guano phosphate formations) [6-8]. 
Beneficiation of phosphate ores is one of the important research subjects in mineral processing studies. After size reduction and classification, the enrichment processing of the phosphate ores may include washing, desliming, magnetic separation, and flotation depending on the types of gangue minerals present. However, flotation is the most common process among them as more than $60 \%$ of the marketable phosphate in the world is produced by flotation [9]. It was reported by Nanthakumar et al. [10] that the anionic flotation of phosphate ores generally relies on the use of fatty acid surfactant-type collectors, and in the case of high-iron phosphate ores, the depression of iron minerals is usually achieved using starch and the use of this polysaccharide in this role is based on the very successful application of various starches in beneficiating hematite-based iron ores [10]. However, the role of reagents utilised in igneous phosphate ores flotation was reviewed by Guimarães et al. [11].

The igneous and metamorphic phosphate deposits such as Bingöl-Genç (Avnik) and Bitlis-Ünaldı ores are very complex and contain mainly magnetite and apatite, and silicates such as amphibole, epidote, diopside and chlorite, carbonates, (calcite, dolomite, siderste, and ankerite), nepheline syenite, pyroxenite, foskorite, etc [12-16]. The major problem of Bingöl-Bitlis ores is the high phosphorus content. Obtaining, both, the iron and phosphate concentrate from these deposits will significantly contribute to the valuation of such ores.

In this study, it has been aimed to obtain both magnetite and apatite concentrates by using magnetic separation and flotation, respectively.

\section{MATERIAL AND METHODS}

\subsection{Material}

In this study, apatite-bearing iron ore sample from Bingöl region was used. The sample was initially crushed below 6.70 $\mathrm{mm}$ and then below $3.35 \mathrm{~mm}$ using laboratory jaw and roll crusher, respectively. The crushed product was ground by rod mill, and then magnetic separation and flotation tests were carried out according to the procedure shown in Fig. 1.

\subsection{Methods}

Magnetic separation: The magnetic separation experiments were performed using a drum type wet lowintensity magnetic separator. Drum rotation speed was selected as $25 \mathrm{rpm}$, pulp density in the mixing tank was adjusted to $10 \%$ of solids by weight. In the first magnetic separation circuit, a rougher magnetic and non-magnetic product were collected. And then, the magnetic product was subjected to two cleaner stages and a final magnetite concentrate was obtained (Fig.1).

Flotation tests: The direct anionic flotation of phosphate minerals was conducted in accordance with the flowsheet shown in Fig. 1. Flotation tests were carried out in a Denver type laboratory flotation machine with $1.5 \mathrm{~L}$ cell. $400 \mathrm{~g}$ of ground samples were used for each test. The conditioning and flotation steps were made at $45 \%$ and $27 \%$ solids concentrations by weight, respectively, while keeping the pulp stirring speed constant at $1500 \mathrm{rpm}$. An industrial-grade distilled tall oil type fatty acid was used as a collector to float phosphate minerals. Sodium metasilicate and corn starch were used as dispersant and depressant, respectively. But, it was demonstrated that sodium silicate could be used not only as a dispersant of slime but also as depressant and activator for some minerals. MIBC was used as the frother and the dosage was fixed at $30 \mathrm{~g} / \mathrm{t}$. $\mathrm{NaOH}$ was used to regulate and control the pulp pH. According to the flowsheet in Fig. 1, in the first part of flotation tests, apatite was floated to obtain rougher apatite concentrate. The rough concentrate was subjected to further flotation process using three cleaner stages. The sink product from rougher flotation test was then transferred to the apatite scavenger stage. In the cleaner and scavenger stages, froth product was scraped for 5 and 3 min., respectively. After the flotation process, a final apatite concentrate and a tailing from scavenger stage, and a middling product attained by combining the middlings from scavenger and cleaner stages were obtained. After carrying out the flotation tests, all products (apatite concentrate, middling, and tailing) were filtered, dried, and weighed. Chemical assays of all products were determined using XRF analysis technique. The flotation recovery was calculated based on the grade and weight of flotation products.

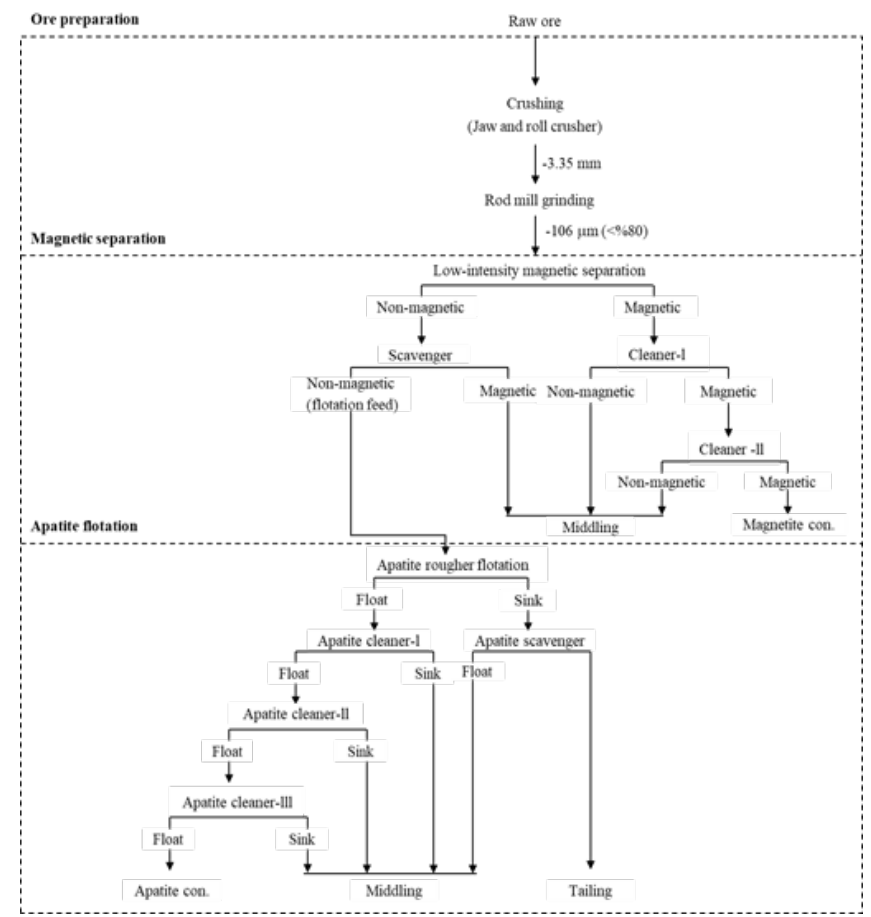

Figure 1. Flowchart of the ore preparation and beneficiation tests procedure.

Characterization techniques: Crystallinity of the samples was determined by X-ray diffraction analysis (XRD) using Rigaku RadB type diffractometer (at the Scientific and Technological Research Center, İnönü University, Malatya). The radiation applied was $\operatorname{CuK} \alpha(\lambda=1.5405 \AA)$ from a long fine focus $\mathrm{Cu}$ tube, operating at $40 \mathrm{kV}$ and $40 \mathrm{~mA}$. The samples were measured in the range of $2-80$ o with $0.02^{\circ}$ steps at a rate of 2 oper min. Data collection and evaluation were performed with the International Centre for Diffraction Data (ICDD). The microstructure was observed by using an LEO Evo 40 model scanning electron microscope (SEM-EDS) The chemical composition of all sample was determined by X-ray fluorescence spectroscopy using the Thermo Scientific ARL ADVANT'X series XRF Spectrometers. The PSD analysis of the ground sample was determined using a Malvern Mastersizer 2000 particle analyser (Malvern Instruments Ltd., UK). The sample was stirred with distilled water at $2000 \mathrm{rpm}$ in a 1-liter cell integrated with the device and in-situ 
measurements were performed. Particle size distribution data were automatically obtained using Mastersizer 2000 software.

\section{RESULTS AND DISCUSSION}

\subsection{Characterization of the ore}

It is well known that the successful applicability of the physical beneficiation methods highly depends on the mineralogical characteristics of the iron ores [1] and the phosphate flotation is strongly influenced by the mineralogical composition of the phosphate ore $[7,17]$. Therefore, mineralogical and chemical characterization of raw ore was carried out before beneficiation tests.

Mineralogical analysis: XRD technique which may be coupled with chemical analysis is essential for characterization study, and applied for many purposes such as ore genesis, mineralization control and mineral processing, etc. In this study, XRD analysis was performed to determine the mineral phases of the raw ore, and the results are illustrated in Fig. 2. According to XRD analysis results, major mineral phases in the ore are apatite $\left(\mathrm{Ca}_{5}\left(\mathrm{PO}_{4}\right)_{3}\left(\mathrm{~F}, \mathrm{Cl}, \mathrm{OH}, \mathrm{CO}_{3}\right)\right)$ (but apatite type could not be distinguished), magnetite $\left(\mathrm{Fe}_{3} \mathrm{O}_{4}\right)$, quartz $\left(\mathrm{SiO}_{2}\right)$, feldspar $\left(\mathrm{NaAlSi}_{3} \mathrm{O}_{8}\right)$, calcite $\left(\mathrm{CaCO}_{3}\right)$, dolomite $\left(\mathrm{CaMg}\left(\mathrm{CO}_{3}\right)\right)$, ilmenite $\left(\mathrm{FeTiO}_{3}\right)$, barite $\left(\mathrm{BaSO}_{4}\right)$, rectorite $\left((\mathrm{Na}, \mathrm{Ca}) \mathrm{Al}_{4}(\mathrm{Si}, \mathrm{Al})_{8} \mathrm{O}_{20}(\mathrm{OH})_{4.2}\left(\mathrm{H}_{2} \mathrm{O}\right)\right)$, muscovite $\left(\mathrm{KAl}_{2}\left(\mathrm{AlSi}_{3} \mathrm{O}_{10}\right)(\mathrm{F}, \mathrm{OH})_{2}\right)$. They are common minerals of phosphate bearing iron deposits, as reported in the literature $[7,13]$.

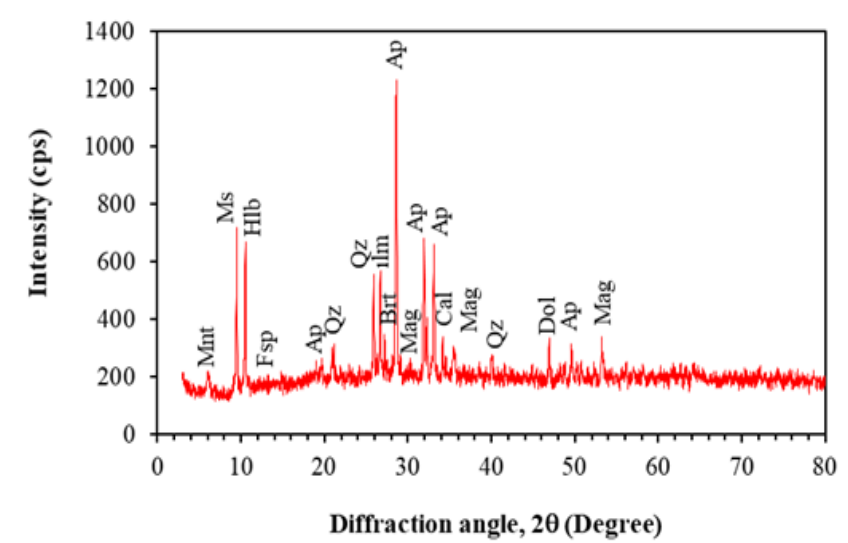

Figure 2. The XRD patterns of raw ore (Mnt: Montmorillonite, Ms: Muscovite, Ap: Apatite, Hlb: Hornblende, Fsp: Feldspar, Qz: Quartz, 1lm: Ilmenite, Brt: Barite, Mag: Magnetite, Cal: Calcite, Dol: Dolomite).

Chemical analysis: Chemical analysis results of the raw ore is given in Tab. 1. The raw ore contains $35.75 \% \mathrm{Fe}$ and $5.36 \% \mathrm{P}_{2} \mathrm{O}_{5}$. From the XRF results it can be seen that the ore sample is an iron rich ore containing phosphate and silicates as main gangue minerals. The raw ore can not be used directly in the iron-steel or fertilizer industries. Therefore, it must be enriched with suitable methods.

TABLE 1

Chemical COMPosition OF THE ORE SAMPLE USED IN THE STUdy

\begin{tabular}{lcccccc}
\hline \hline Compound & $\mathrm{Fe}$ & $\mathrm{P}_{2} \mathrm{O}_{5}$ & $\mathrm{SiO}_{2}$ & $\mathrm{Al}_{2} \mathrm{O}_{3}$ & $\mathrm{CaO}$ & $\mathrm{MgO}$ \\
\hline Content $(\%)$ & 35.75 & 5.36 & 27.25 & 6.12 & 10.18 & 0.68 \\
\hline & $\mathrm{K}_{2} \mathrm{O}$ & $\mathrm{Na}_{2} \mathrm{O}$ & $\mathrm{TiO}_{2}$ & $\mathrm{MnO}$ & LOI* & \\
\hline & 0.05 & 1.58 & 0.30 & 0.01 & 4.5 &
\end{tabular}

* Loss on ignition $\left(1000^{\circ} \mathrm{C}\right)$

\subsection{Beneficiation tests}

Magnetic separation test results: Phosphorous is a major contaminant for the vast majority of uses of iron ores, especially all related to iron making. It is found in a variety of forms from separate phosphate minerals to intimate association with iron hydroxide phases. When phosphate minerals can be traced as the major source of phosphorus, physical separation methods are feasible. The phosphorous removal of such ores can be normally carried through magnetic separation and flotation [18].

Magnetic separation test results are presented in Tab. 2. The results show that low-grade iron ore can be enriched by magnetic separation. It can be seen that the quality of magnetite product was improved in terms of chemical composition, especially for grades of $\mathrm{Fe} \%$ and $\mathrm{P}_{2} \mathrm{O}_{5} \%$ compared to the content of the original ore. For example, $\mathrm{Fe}$ grade of raw ore increased from $35.75 \%$ to $63.55 \%$ with $80.40 \%$ Fe recovery.

TABLE 2

Magnetic Separation Test Results

\begin{tabular}{lccccc}
\hline \hline Product & Weight & \multicolumn{2}{c}{ Grade $\%$} & \multicolumn{2}{c}{ Recovery \% } \\
\cline { 3 - 6 } & $(\%)$ & $\mathrm{Fe}$ & $\mathrm{P}_{2} \mathrm{O}_{5}$ & $\mathrm{Fe}$ & $\mathrm{P}_{2} \mathrm{O}_{5}$ \\
\hline Magnetite Conc. & 45.23 & 63.55 & 1.65 & 80.40 & 13.92 \\
Middling & 15.68 & 24.06 & 3.42 & 7.19 & 10.00 \\
Tailing/Non-mag & 39.09 & 10.06 & 10.43 & 12.41 & 76.06 \\
Feed & 100 & 35.75 & 5.36 & 100 & 100 \\
\hline \hline
\end{tabular}

The full chemical analysis of the magnetite concentrate was also carried out and the results are given in Tab. 3. It can be concluded that a reasonable magnetite concentrate (can be used in iron and steel production and fed into the blast furnace) has been obtained by magnetic separation, except for the phosphate phase. However, the concentrate still contains a critical amount of phosphorus $(1.65 \%)$.

TABLE 3

Full Chemical ANAlysis of Magnetite ConCENTRATE

\begin{tabular}{ccccccc}
\hline \hline Compound & $\mathrm{Fe}$ & $\mathrm{P}_{2} \mathrm{O}_{5}$ & $\mathrm{SiO}_{2}$ & $\mathrm{Al}_{2} \mathrm{O}_{3}$ & $\mathrm{CaO}$ & $\mathrm{MgO}$ \\
\hline Content $(\%)$ & 64.73 & 1.62 & 6.36 & 2.22 & 1.94 & 2.16 \\
\hline & $\mathrm{K}_{2} \mathrm{O}$ & $\mathrm{Na}_{2} \mathrm{O}$ & $\mathrm{TiO}_{2}$ & $\mathrm{MnO}$ & $\mathrm{S}$ & \\
\hline & 0.11 & 0.68 & 0.25 & 0.05 & 0.5 & \\
\hline \hline
\end{tabular}

Chemical analysis results are also supported with XRD and SEM-EDS images given in Fig. 3 and Fig.4. When XRD patterns of the magnetic product (or magnetite concentrate) from magnetic separation were examined, it was observed that the peak intensity of magnetite dramatically increased at around $35^{\circ} 2 \theta$ (Fig. 3). The predominance of magnetite peaks indicates that magnetite is more abundant in magnetic concentrate. Although other peaks such as apatite are relatively declined, they are still present in the magnetic product.

As know, the combination of scanning electron microscopy-energy dispersive X-ray spectrometry (SEMEDS) enable the chemical characterization of bulk and surface of individual particles. It can be observed from EDS spectrum of magnetic product that $\mathrm{Fe}$ exhibits very high distribution (95.95 wt.\%). 


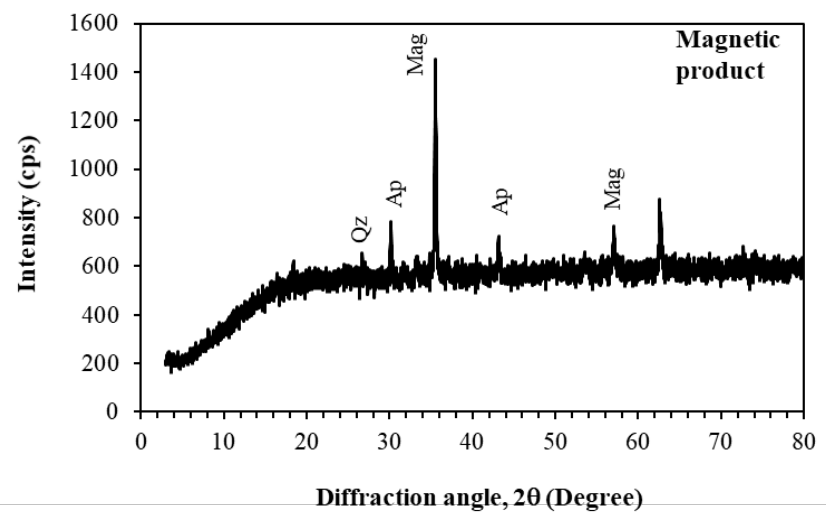

Figure 3. XRD patterns of the magnetic product obtained by low-intensity magnetic separation.

It indicates that main mineral phase in magnetic concentrate is magnetite, but, according to SEM observations, free particles consisting of single mineral phase in the mapping images are very rare, indicating poor mineral liberation as a result of intergrowth relationship with magnetite and phosphate mineral phases (Fig.4).

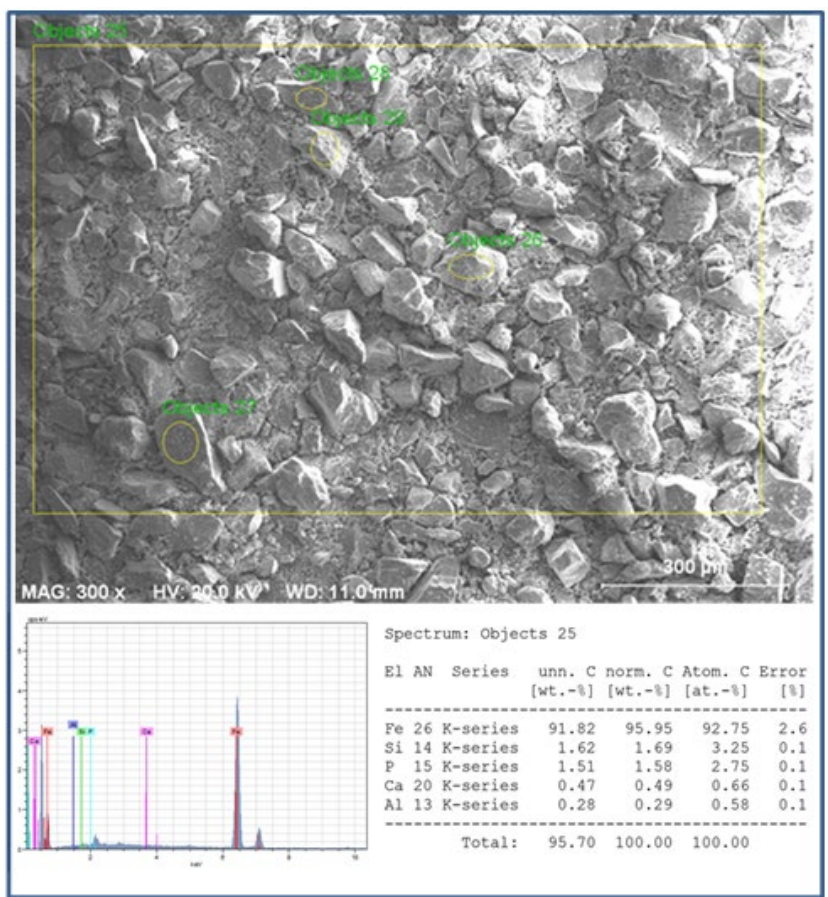

Figure 4. SEM-EDS images of the magnetite particles from magnetic separation.

Flotation test results: It is well known that the flotation performance strongly depends on particle size and liberation of the valuable mineral $[19,20]$. Also, previous studies have shown that the particle size distribution of milling ore has an essential effect on metallurgical results of phosphate flotation [21]. The particle size distribution of the flotation feed, the non-magnetic product of the magnetic separation, is shown in Fig. 5. As seen from the Fig. 5, d(50) value is about $80 \mathrm{~mm}$. However, the slope of the curve becomes slightly steeper and indicates a narrow particle size distribution. According to the literature, narrow feed size distribution may have a positive effect on flotation process compared to large particle size distribution [22].

Magnetic separation tailling (i.e. non-magnetic product) was subjected to flotation process to obtain apatite concentrate. An industrial-grade distilled tall oil type collector (tall oil+fuel oil, $800 \mathrm{~g} / \mathrm{t}$ of dosage) was used as an apatite collector. As dispersant of slime, sodium metasilicate $\left(\mathrm{Na}_{2} \mathrm{SiO}_{3}\right)$ solution (about $\left.40 \%\right)$ was used to disperse silicate gangue minerals. Also, soluble corn starch $\left(\left(\mathrm{C}_{6} \mathrm{H}_{10} \mathrm{O}_{5}\right)_{\mathrm{n}}\right.$ was used as depressant for iron minerals. The dosages of the sodium silicate and corn starches were 1200 and $1000 \mathrm{~g} / \mathrm{t}$, respectively. MIBC was used as the frother and the dosage was fixed at $30 \mathrm{~g} / \mathrm{t}$. $\mathrm{NaOH}$ was used to regulate and control the pulp $\mathrm{pH}$ at 9.5. Phosphate concentrate obtained by rougher flotation was subjected to three cleaning circuits to obtain high-grade phosphate concentrates.

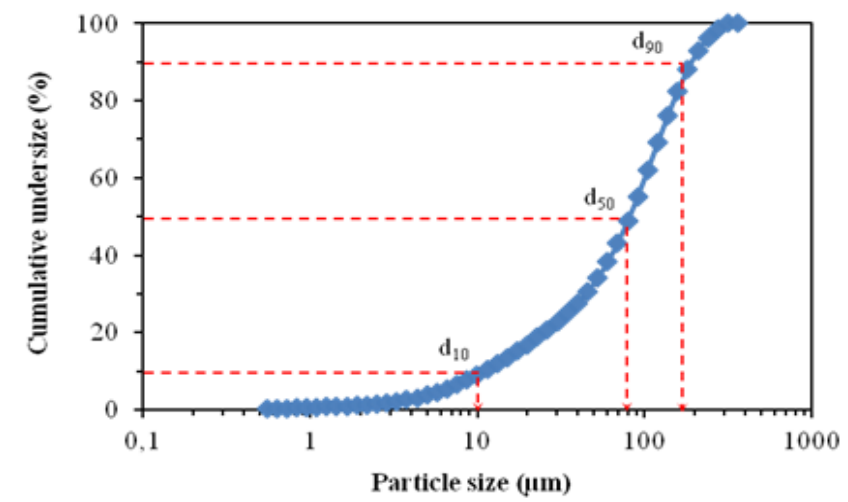

Figure 5. Particle size distribution of the flotation feed (i.e non-magnetic product from magnetic separator).

Flotation results presented in Tab. 4 clearly show that there is an improvement in $\mathrm{P}_{2} \mathrm{O}_{5}$ grade of the phosphate concentrate. It can be seen that the quality of concentrate was improved in terms of $\mathrm{P}_{2} \mathrm{O}_{5}$ and $\mathrm{Fe}$ grades, compared to the content of the original ore. A high-grade phosphate concentrate containing $25.33 \% \mathrm{P}_{2} \mathrm{O}_{5}$ was obtained with $64.89 \%$ recovery. However, the relatively higher iron content $(6.45 \% \mathrm{Fe})$ implies that $\mathrm{Fe}-$ bearing minerals may be present in concentrate. According to a recent study by Nakhaei and Irannajad [23], starch is a depressing and flocculating agent for various minerals but normally used as a depressant for iron oxides. However, it should be emphasized that the composition and interlocking of iron-bearing minerals are very critical in phosphate flotation. In cases where the magnetite is intimately intergrown with phosphate minerals (i.e. apatite), such particles tend to either float (i.e. going up to concentrate or middling) or sink (i.e. remaining to tailling) depending on the flotation conditions. As a result, interlocked mineral particles are the most important handicap to selective flotation, and it is very difficult to predict their behavior in flotation.

TABLE 4

Direct ANiOnic Flotation of ApATITE

\begin{tabular}{lccccc}
\hline \hline Product & Weight & \multicolumn{2}{c}{ Grade \% } & \multicolumn{2}{c}{ Recovery \% } \\
\cline { 3 - 6 } & $(\%)$ & $\mathrm{P}_{2} \mathrm{O}_{5}$ & $\mathrm{Fe}$ & $\mathrm{P}_{2} \mathrm{O}_{5}$ & $\mathrm{Fe}$ \\
\hline Apatite Conc. & 26.72 & 25.33 & 6.45 & 64.89 & 17.13 \\
Middling & 18.39 & 9.47 & 8.49 & 16.70 & 15.52 \\
Tailing & 54.89 & 3.50 & 12.34 & 18.42 & 67.33 \\
Feed & 100 & 10.43 & 10.06 & 100 & 100 \\
\hline \hline
\end{tabular}

XRD pattern and SEM-EDS images of the apatite concentrate are shown in Fig. 6 and Fig. 7, respectively. Based on attrition-direct flotation, the results of XRD analysis confirmed that apatite minerals were enriched in flotation concentrate. In the apatite concentrate, the major crystalline 
phase is apatite, XRD intensity of which is sharply increased by flotation. However, apatite flotation causes the intensity of magnetite reflection to decrease significantly, but never completely disappear (Fig. 6).

According to EDS spectrum of the flotation concentrate in Fig. 7, the total distribution of $\mathrm{Ca}$ and $\mathrm{P}$ elements is 83.89 wt.\% and much higher than other elements. It indicates that the abundant mineral phase in flotation concentrate is phosphate minerals such as apatite, but also carries less amount of silica (e.g. quartz) and other mineral phases such as iron oxides (e.g. magnetite). Although the mineral source of fluor $(\mathrm{F})$ in the ore is unrecognized, it may indicate fluorapatite $\left(\mathrm{Ca}_{5}\left(\mathrm{PO}_{4}\right)_{3} \mathrm{~F}\right)$.

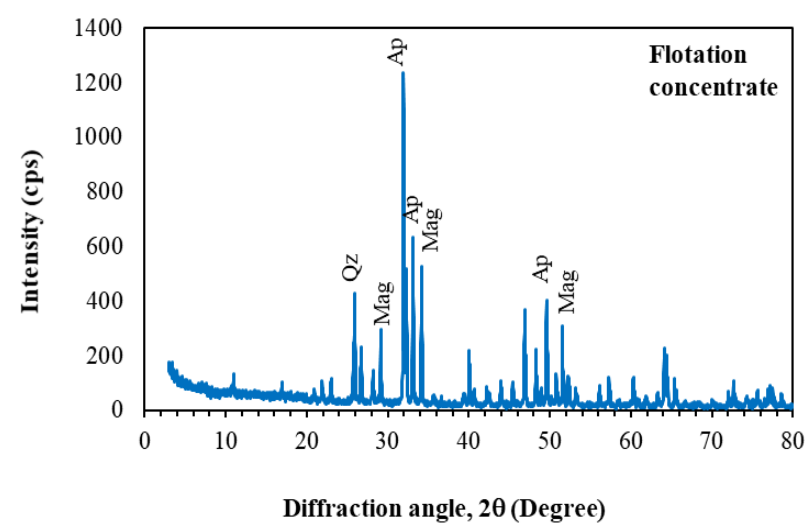

Figure 6. XRD patterns of flotation concentrate (i.e. apatite conc.).

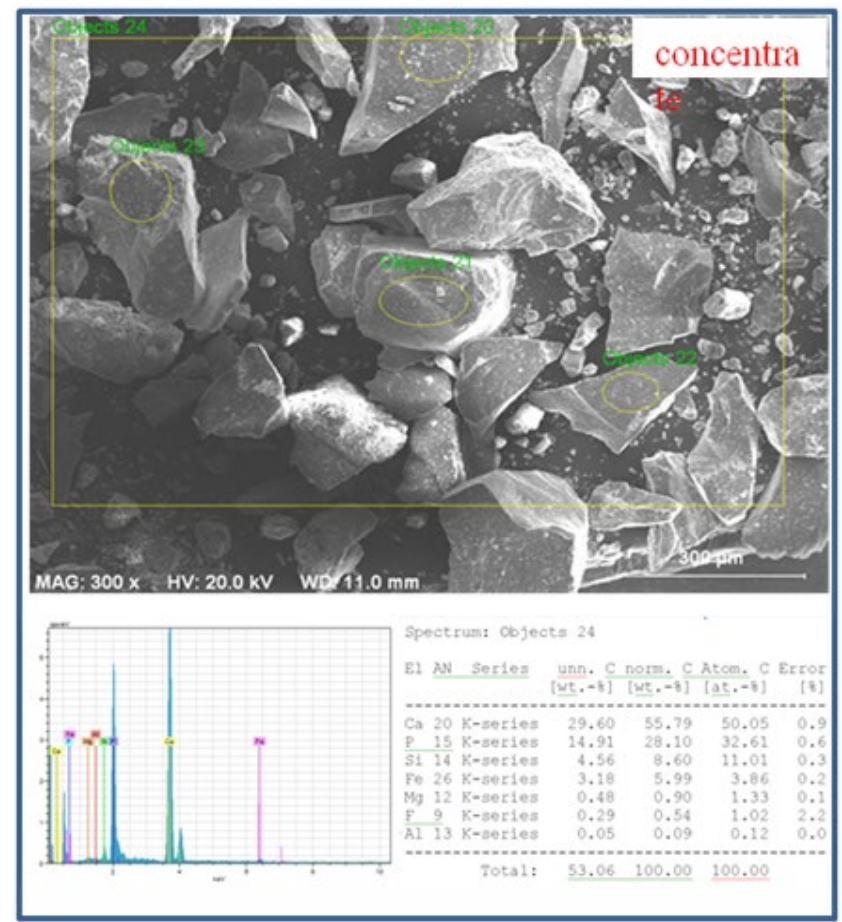

Figure 7. SEM-EDS images of flotation concentrate (i.e. apatite conc.).

As seen in the XRD pattern of flotation tailing in Fig. 8, the peak intensities of silicate minerals dramatically increased. The highest peak by appearing at around $26.5^{\circ} 2 \theta$ is the typical peak of quartz. XRD results emphasize that the tailing is mostly composed of gangue minerals, but it also includes phosphate and iron phases.

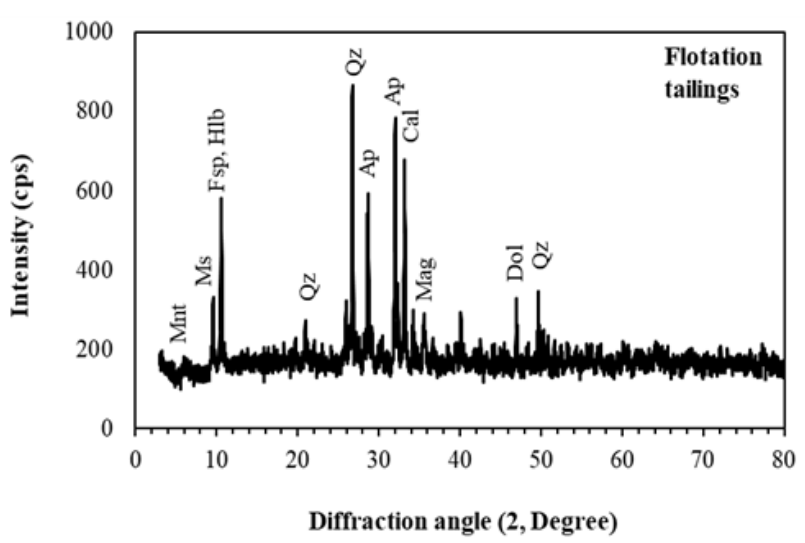

Figure 8. XRD patterns of flotation tailing.

The distribution of Fe and Si element in the EDS spectrum of tailing particles in Fig. 9 is 29.78 wt.\% and 24.70 wt.\%, respectively, implying that iron and silica mineral phases are more in tailings, as expected. Also, the tailing particle contains a significant amount of $\mathrm{Ca}$ (23.52 wt.\%) and $\mathrm{P}$ (12.58 wt.\%). Source of $\mathrm{Ca}$ in the flotation tailing comes from phosphate or largely carbonate minerals like calcite and dolomite.

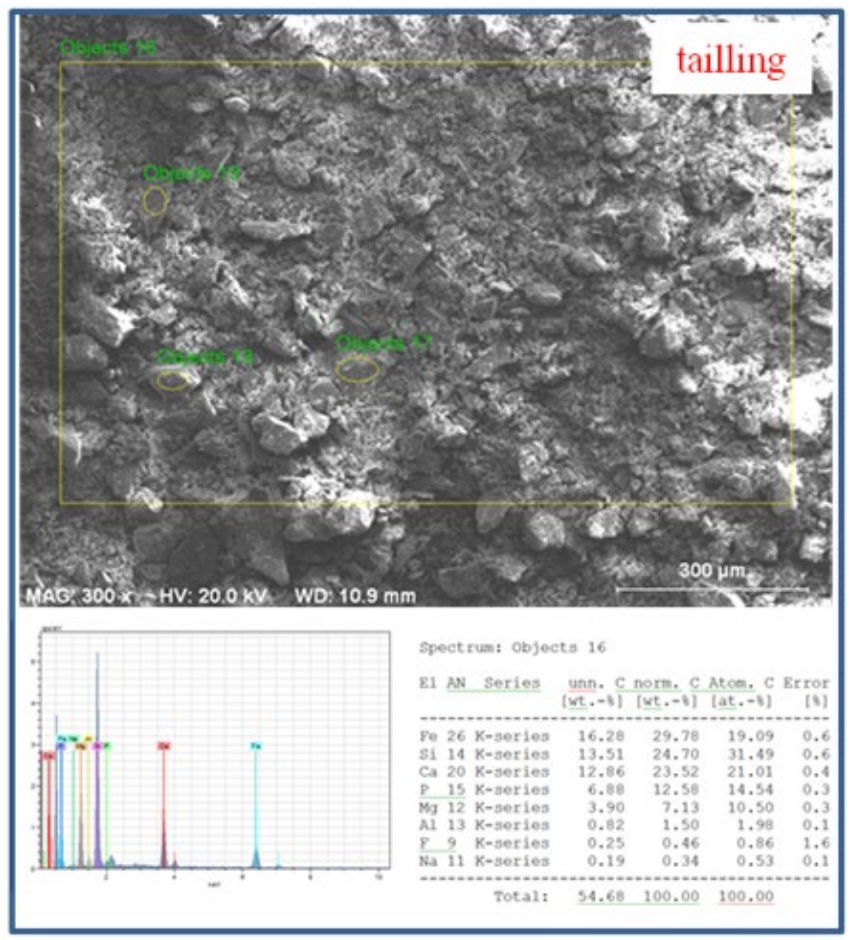

Figure 9. SEM-EDS images of flotation tailing.

\section{CONCLUSION}

In this study, the concentration of apatite-bearing iron ore from Bingöl region with low $\mathrm{Fe}$ and high $\mathrm{P}_{2} \mathrm{O}_{5}$ contents was investigated by utilizing consecutive magnetic separation and froth flotation. The following conclusions were drawn from this study:

1) As a result of magnetic separation processes, a concentrate having $63.55 \% \mathrm{Fe}$ and $1.65 \% \mathrm{P}_{2} \mathrm{O}_{5}$ grade was obtained with an $80.40 \%$ recovery from the raw ore containing $35.75 \%$ Fe and $5.36 \% \mathrm{P}_{2} \mathrm{O}_{5}$. However, the phosphorus content of the magnetite concentrate is critical for the iron and steel industry. Nevertheless, harmful impurities such as $\mathrm{SiO}_{2}$, 
$\mathrm{Al}_{2} \mathrm{O}_{3}, \mathrm{MgO}, \mathrm{K}_{2} \mathrm{O}$, and $\mathrm{Na}_{2} \mathrm{O}$ have been reduced to the plausible level demanded by the iron and steel industry.

2) In order to obtain high-grade apatite concentrate with high apatite recovery, cleaning and scavenging stages are required. The batch flotation test with three cleaning stage increased the $\mathrm{P}_{2} \mathrm{O}_{5}$ content in the concentrate from $10.43 \%$ to $25.33 \%$ and decreased the Fe content from $10.06 \%$ to $6.45 \%$. Unfortunately, $\mathrm{P}_{2} \mathrm{O}_{5}$ grade is still low for marketable phosphate concentrate, and $\mathrm{Fe}$ content in the concentrate was still high for the fertilizer industry.

3) The higher quality phosphate concentrate could not be obtained, probably due to mineralogical composition of the ore such as interlocking of $\mathrm{Fe}$-oxides with phosphate minerals and the lack of mineral liberation.

\section{ACKNOWLEDGEMENT}

This study was carried out in the Mining Engineering Department of İnönü University, Mineral Processing Laboratories.

\section{REFERENCES}

[1] S.K. Roy, D. Nayak, S.S. Rath, "A review on the enrichment of iron values of low-grade iron ore resources using reduction roastingmagnetic separation," Powder Technology, vol. 367, pp. 796-808, 2020.

[2] A.C. Pereira, R.M. Papini, "Processes for phosphorus removal from iron ore-a review," REM: Revista Escola de Minas, vol. 68, no. 3, pp. 331-335, 2015

[3] Y. Mochizuki, N. Tsubouchi, "Removal of gangue components from low-grade iron ore by hydrothermal treatment," Hydrometallurgy, vol. 190, article no. 105159, 2019.

[4] S.S. Rath, H. Sahoo, N. Dhawan, "Optimal recovery of iron values from a low grade iron ore using reduction roasting and magnetic separation," Separation Science and Technology, vol. 49, no. 12, pp. 1927-1936, 2014.

[5] F.W. Su, K.H. Rao, K.S.E. Forssberg, P.O. Samskog, "The influence of temperature on the kinetics of apatite flotation from magnetite fines," International Journal of Mineral Processing, vol. 54, no. 3-4, pp. $131-145,1998$

[6] U.S.G.S. "Mineral Commodity Summaries, Phosphate Rock," U.S. Geological Survey, 2003.

[7] A.M. Abouzeid, "Upgrading of Phosphate Ores-A Review," The Journal of Ore Dressing, vol. 9, no. 17, pp. 10-32, 2007.

[8] P.V. Straaten, "Rocks for Crops: Agrominerals of sub-Saharan AfricaRocks for Crops," Department of Land Resource Science, Canada, 2002.

[9] G. Baudet, "The Processing of Phosphate Ores," Chron. Rch. Miner., Special Issue on Phosphates, 1988.

[10] B. Nanthakumar, D. Grimm, M. Pawlik, "Anionic flotation of highiron phosphate ores-Control of process water chemistry and depression of iron minerals by starch and guar gum," International Journal of Mineral Processing, vol. 92, no. 1-2, pp. 49-57, 2009.

[11] R.C. Guimarães, A.C. Araujo, A.E.C. Peres, "Reagents in igneous phosphate ores flotation," Minerals Engineering, vol. 18, no. 2, pp. 199-204, 2005.

[12] D.P.T. "Madencilik ÖİK Endüstriyel Hammaddeler Alt Komisyonu, Gübre Sanayii Hammaddeleri Çalışma Grubu Raporu Fosfat, Kükürt, Potas," T.C. Başbakanlık Devlet Planlama Teşkilatı Müsteşarlığı, Yayın No: 2437, 1996.

[13] B. Erdoğan, O.Ö. Dora, "Bitlis masifi apatitli demir yataklarının jeolojisi ve oluşumu," Türkiye Jeoloji Kurumu Bülteni, vol. 26, pp. 133-144, 1983.

[14] C. Helvacı, "Apatite-Rich Iron Deposits of the Avnik (Bingöl) Region, Southeastern Turkey," Economic Geology, vol. 79, no. 2, pp. 354-371, 1984(a).

[15] C. Helvacı, "Bitlis Masifi Avnik (Bingöl) yöresi apatitli demir yataklarının oluşumu," Jeoloji Mühendisliği, vol. 19, pp. 33-51, 1984(b)

[16] H. Çelebi, "Türkiye Apatitli Manyetit Yatakları: Jeolojisi, Jeokimyası ve Ekonomik Potansiyeli," İstanbul Yerbilimleri Dergisi, vol. 22, no.1, pp. 67-83, 2009.
[17] L.A.F. Barros, E.E. Ferreira, A.E.C. Peres, "Floatability of apatites and gangue minerals of an igneous phosphate ore," Minerals Engineering, vol. 21, pp. 994-999, 2008

[18] A.P.L. Nunes, A. C. Araujo, P .R. M. Viana, A. B. Henriques, "Revisiting phosphate separation from iron ores," ANNALS - 3rd International Meeting on Ironmaking and 2nd International Symposium on Iron Ore, Brazil, pp. 265-275, 2008.

[19] W.J. Trahar, "A rational interpretation of the role of particle size in flotation," International Journal of Mineral Processing, vol. 8, pp. 289327, 1981.

[20] N.W. Johnson, "Existing methods for process analysis, Flotation Plant Optimisation A Metallurgical Guide to Identifying and Solving Problems in Flotation Plants," Edited by C.J. Greet. Spectrum Series No 16. The Australasian Institute of Mining and Metallurgy, Chapter 2. pp. 35-64, 2010.

[21] D. Feng, C. Aldrich, "Influence of operating parameters on the flotation of apatite," Minerals Engineering, vol. 17, no. 3, pp. 453-455, 2004.

[22] C.P. Massola, A. P. Chaves, J. R. B. Lima, C. F. Andrade, "Separation of silica from bauxite via froth flotation," Minerals Engineering, vol. 22, no. 4, pp. 315-318, 2009.

[23] F. Nakhaei, M. Irannajad, "Reagents types in flotation of iron oxide minerals: A review," Mineral Processing Extractive Metallurgy Review, vol. 39, pp. 89-124, 2018.

\section{BIOGRAPHIES}

Mustafa Birinci obtained his BSc degree in mining engineering from Karadeniz Technical University (KTU) in 1997. He received the BSc., and MSc. diploma in Mining Engineering from the Karadeniz Technical University and İnönü University in 1997 and 2002 respectively, and $\mathrm{PhD}$ degrees in Graduate School of Naturel and Applied Science, Department of Mining Engineering of the same university in 2011. He was awarded a grant (2214-International Research Fellowship Programme for PhD Students) by The Scientific and Technological Research Council of Turkey (TUBITAK), and studied at The University of Utah, Metallurgical Engineering between 2009-2010 (9 months).

His research interests are mineral processing and coal preparation, especially the concentration of metallic and industrial minerals by froth flotation. He has recently focused on hydrometallurgical processing of industrial minerals such as clay minerals. In 1998 he joined the Engineering Faculty, İnönü University as a research assistant, where he is presently an assistant professor. He is active in teaching and research in mineral processing. 